\title{
Development of gene-based molecular markers tagging low alkaloid pauper locus in white lupin (Lupinus albus L.)
}

\author{
Sandra Rychel ${ }^{1} \cdot$ Michał Książkiewicz $^{1}$ (1) \\ Received: 2 April 2019 /Revised: 2 July 2019 / Accepted: 18 July 2019/Published online: 13 August 2019 \\ (C) The Author(s) 2019
}

\begin{abstract}
White lupin (Lupinus albus L.) is a legume grain crop cultivated since ancient Greece and Egypt. Modern white lupin cultivars are appreciated as a source of protein with positive nutraceutical impact. However, white lupins produce anti-nutritional compounds, quinolizidine alkaloids, which provide bitter taste and have a negative influence on human health. During domestication of this species, several recessive alleles at unlinked loci controlling low alkaloid content were selected. One of these loci, pauper, was exploited worldwide providing numerous low-alkaloid cultivars. However, molecular tracking of pauper has been hampered due to the lack of diagnostic markers. In the present study, the synteny-based approach was harnessed to target pauper locus. Single-nucleotide polymorphisms flanking pauper locus on white lupin linkage map as well as candidate gene sequences elucidated from the narrow-leafed lupin (L.angustifolius L.) chromosome segment syntenic to the pauper linkage group region were transformed to PCR-based molecular markers. These markers were analyzed both in the mapping population and world germplasm collection. From fourteen markers screened, eleven were localized at a distance below $1.5 \mathrm{cM}$ from this locus, including five co-segregating with pauper. The linkage of these markers was confirmed by high LOD values (up to 58.4). Validation performed in the set of 127 bitter and 23 sweet accessions evidenced high applicability of one marker, LAGI01_35805_F1_R1, for pauper locus selection, highlighted by the low ratio of false-positive scores $(2.5 \%)$. LAGI01_35805 represents a homolog of $L$. angustifolius acyltransferase-like (LaAT) gene which might hypothetically participate in the alkaloid biosynthesis process in lupins.
\end{abstract}

Keywords White lupin $\cdot$ Alkaloids $\cdot$ Molecular markers $\cdot$ Linkage mapping

\section{Introduction}

White lupin (Lupinus albus L.) is a cool season grain legume crop with a relatively long history of cultivation. Primary domestication of L. albus has occurred in ancient Greece and Egypt to produce grain for human and animal consumption as well as in ancient Rome as green manure (Gladstones 1970). Lupins were found to be very beneficial in crop

Communicated by: Barbara Naganowska

Electronic supplementary material The online version of this article (https://doi.org/10.1007/s13353-019-00508-9) contains supplementary material, which is available to authorized users.

Michał Książkiewicz

mksi@ igr.poznan.pl

1 Institute of Plant Genetics, Polish Academy of Sciences, Strzeszyńska 34, 60-479 Poznań, Poland rotations because they increase soil fertility through symbiotic nitrogen fixation and efficient mobilization of soil phosphorus (Lambers et al. 2013). Modern lupin cultivars are appreciated also as a valuable source of protein (38-42\% in seeds) (Papineau and Huyghe 2004) with positive nutraceutical impact on hypercholesterolemia, hypertension, and hyperglycemia (Arnoldi and Greco 2011). Moreover, white lupin crops have moderate seed content of oil (10-13\%) with desirable ratios of omega- 6 to omega- 3 acids for consumption purposes (Boschin et al. 2007). These advantages make this species valuable for human food and animal feed (Lin et al. 2009). However, white lupin seeds contain some content of anti-nutritional compounds, including quinolizidine alkaloids (up to $12 \%$ in wild populations) and oligosaccharides (up to 10\%) (Kroc et al. 2017; Mohamed and RayasDuarte 1995). Average total alkaloid content in white lupin breeding lines and cultivars is about $1.3 \%$ of the seed dry weight; however, in some sweet accessions, these values are below $0.02 \%$ (Kroc et al. 2017). 
Alkaloids are considered as the major unfavorable components in white lupin due to their bitter taste and negative influence on human health, causing in the worst-case scenario acute anticholinergic toxicity (Daverio et al. 2014). Therefore, during the domestication process, numerous efforts aiming at the reduction of alkaloid levels were strongly emphasized. As many as nine hypothetical loci controlling low alkaloid content were initially identified throughout white lupin breeding, including pauper, primus, tercius, exiguus, nutricius, mitis, suavis, reductus, and minutus (Hackbarth 1957; Hackbarth 1961; Porsche 1964; Šatović 1993; Troll 1958). However, primus and tercius were identified as the synonyms of pauper, whereas suavis and minutus were not studied as extensively as the other loci and their independence cannot be authenticated (Harrison and Williams 1982). Three low-alkaloid alleles originating from different loci were introduced into white lupin cultivars in the early years of modern domestication, namely exiguus (cv. Neuland, 1937), pauper (cv. Kraftquell, cv. Ultra, and cv. Przebędowski Wczesny, 1949-1950), and nutricius (cv. Nahrquell, 1949); nevertheless, only a pauper was exploited worldwide (Harrison and Williams 1982; Šatović 1993).

To facilitate molecular studies on white lupin domestication genes, a recombinant inbred line (RIL) mapping population was developed, descending from parental cross between Kiev Mutant (Ukrainian cv, sweet, early flowering, anthracnose susceptible) and P27174 (Ethiopian landrace, bitter, late flowering, anthracnose resistant) (Phan et al. 2007). A linkage map carrying 220 amplified fragment length polymorphism (AFLP) and 105 PCR-amplified gene-based markers was developed for this RIL population, but the distance between the pauper locus and flanking markers was revealed to be higher than $20 \mathrm{cM}$ in both directions (Phan et al. 2007). This map was later updated with the set of 136 diversity array technology (DArT) markers but no improvement around the pauper locus was achieved as the flanking markers were split into two separate linkage groups (Vipin et al. 2013). With the aid of the microsatellite-anchored fragment length polymorphism (MFLP) technique, the PauperM1 marker was developed, which was confirmed in the Kiev Mutant $\times$ P27174 RIL population to be linked to the pauper locus at the genetic distance of $1.4 \mathrm{cM}$ (Lin et al. 2009). However, this marker required sequencing gel and radioisotope primer labelling for the correct determination of alleles. Moreover, the applicability of this marker was restricted to $\sim 95 \%$ of bitter lines and $91 \%$ of sweet non-pauper lines (Lin et al. 2009). Recently, a highdensity consensus linkage map of white lupin genome was constructed, which integrated 453 published markers with 3597 newly developed sequence-based markers and constituted a single linkage group per every chromosome (Książkiewicz et al. 2017). This map yielded several new markers co-segregating or localized closer to the pauper locus than the PauperM1. Moreover, this new reference linkage map anchored recently published transcriptome assembly (O’Rourke et al. 2013) to particular markers, and aligned these markers to syntenic blocks of the narrow-leafed lupin (L. angustifolius L.) genome sequence (Hane et al. 2017), providing novel opportunities for tracking white lupin domestication genes by comparative mapping approach.

In the present study, these resources were harnessed to analyze the genome region carrying low-alkaloid pauper locus. PCRbased markers were developed and implemented for the screening of white lupin germplasm collection carrying a diversified subset of sweet and bitter lines. The applicability of newly developed markers for pauper allele selection has been evaluated.

\section{Materials and methods}

\section{Plant material}

Genetic mapping was performed using the reference $L$. albus Kiev Mutant $\times$ P27174 recombinant inbred line (RIL) population $\left(\mathrm{F}_{8}, n=195\right)$, delivered by the Department of Agriculture and Food, Western Australia. This population was derived from a cross between a bitter, late flowering, and anthracnose-resistant Ethiopian landrace (P27174) and a sweet, early flowering, and anthracnose susceptible Ukrainian cultivar (Kiev Mutant) (Książkiewicz et al. 2017; Phan et al. 2007; Vipin et al. 2013).

The set of $160 \mathrm{~L}$. albus lines derived from the European Lupin Gene Resources Database maintained by Poznań Plant Breeders Ltd. station located in Wiatrowo was used for marker validation: 79 primitive populations, 36 landraces, 30 cultivars, 12 cross derivatives, and 3 mutants. These lines originated from 23 countries. Taking into consideration alkaloid content in seeds, 127 lines were bitter (above $0.5 \%$ of total dry weight alkaloid content), 26 were sweet (below $0.2 \%$ ), and 7 intermediate (Kroc et al. 2017) (Supplementary File 1).

Plants were grown in a greenhouse at the Institute of Plant Genetics of the Polish Academy of Sciences in Poznań under ambient long-day photoperiod (14-16 h). Leaves were collected from 4-week plants. DNA was isolated using DNeasy Plant Mini Kit (Qiagen, Hilden, Germany).

\section{Development of PCR-based markers}

Marker sequences surrounding pauper locus (Książkiewicz et al. 2017) were aligned to the transcriptome datasets of Kiev and P27174 lines (Książkiewicz et al. 2017) as well as to the reference white lupin gene index LAGI01 (O'Rourke et al. 2013) by BLAST (Altschul et al. 1990) using Geneious software (Kearse et al. 2012). Matching transcripts were then comparatively mapped to the genome sequence of the narrowleafed lupin (Hane et al. 2017), extracting selected loci with $10000 \mathrm{nt}$ of flanking regions. To find exon/intron boundaries, 
white lupin marker and transcript sequences were assembled together with extracted narrow-leafed lupin genome regions into contigs using a progressive Mauve algorithm (Darling et al. 2004) assuming genome collinearity. Mauve alignments carrying markers, corresponding white lupin transcripts and fragments of narrow-leafed lupin scaffolds, were searched for the presence of polymorphic loci. Primers flanking these loci were designed using Primer3Plus (Untergasser et al. 2007).

PCR was performed using Labcycler thermocycler (SensoQuest GmbH, Göttingen, Germany). GoTaq® G2 Flexi DNA Polymerase (Promega) was used. The reaction mixture contained DNA template $(2.5 \mathrm{ng} / \mu \mathrm{L})$, dNTP $(0.8 \mathrm{mM}), \mathrm{MgCl}_{2}(2 \mathrm{mM})$, polymerase $(1 \mathrm{U})$, polymerase buffer $(1 \times)$, and primers $(0.25 \mu \mathrm{M}$ each).

PCR amplicons were purified directly from the postreaction mixtures (QIAquick PCR Purification Kit; Qiagen) and sequenced (ABI PRISM 3130 XL Genetic Analyzer; Applied Biosystems, Hitachi) in the Laboratory of Molecular Biology Techniques, Faculty of Biology, Adam Mickiewicz University (Poznan, Poland). Cleaved amplified polymorphic sequence (CAPS) (Konieczny and Ausubel 1993) or derived CAPS (dCAPS) (Neff et al. 1998) approaches were used to resolve the nucleotide substitution polymorphisms. Restriction sites and dCAPS primers were identified using dCAPS Finder 2.0 (Neff et al. 2002) and SNP2CAPS (Thiel et al. 2004). Restriction products were separated by agarose gel electrophoresis, with the agarose concentration $(1-3 \%)$ adjusted to follow the size of the expected digestion products.

\section{Linkage mapping}

Chi-square $\left(\chi^{2}\right)$ values for Mendelian segregation in $\mathrm{F}_{8}$ RILs were estimated using the expected 1:1 segregation ratio. The calculation of probability was based on $\chi^{2}$ and 2 degrees of freedom. L. albus marker segregation files (Książkiewicz et al. 2017; Phan et al. 2007; Rychel et al. 2019; Vipin et al. 2013), together with those developed in this study, were imported to Joinmap 5.0 (Stam 1993). Mapping procedure was performed as previously described (Książkiewicz et al. 2017). Based on the initial results of the mapping, the line RIL-169 was removed from the final mapping due to the frequent change of marker allelic phases. Such an observation may result from seed admixture or cross-pollination during seed multiplication. Twenty repeats of linkage group calculation with altered parameters were done to estimate the plausibility of marker positions. LOD values were calculated in Map Manager QTXb20 (Manly et al. 2001).

\section{Marker validation}

Markers were validated by comparing seed dry weight alkaloid content (Kroc et al. 2017) and marker allelic phases for the set of 160 collection lines. The Pearson product-moment correlation coefficient was calculated in Excel. Taking into consideration the hypothesis on the influence of a single gene (in the pauper locus) on the alkaloid content, binary data similarity analysis was performed. Therefore, alkaloid content values above $0.2 \%$ were assigned as 1 (bitter and intermediate) and the remaining values as 0 (sweet), however, known as nonpauper low alkaloid lines were assigned as 1 to avoid unjustified false-negative results. Kiev Mutant-like scores were assigned as 0, P27174-like scores as 1, and heterozygotes also as 1 because pauper is a recessive allele. Simple matching (Sokal and Michener 1958) and Rogers-Tanimoto (Rogers and Tanimoto 1960) coefficients were calculated using binary similarity calculator http://www.minerazzi.com/tools/similarity/binarysimilarity-calculator.php.

\section{Results}

\section{Selection of sequences from pauper locus}

Molecular markers from the most recent $L$. albus linkage map localized in the proximity of the pauper locus were aligned to the L. angustifolius genome and gene sequences (Hane et al. 2017) as well as to the L. albus transcriptome (O'Rourke et al. 2013) to find anchors for primer design. Based on the alignments and positions on the linkage map, 6 markers were selected (TP16854, TP22150, TP30216, TP309728, TP447859, TP70046) for further study. One of these markers, TP16854, matched Lup021586 gene, which was shown to have $100 \%$ nucleotide identity to the LaAT gene (AB581532.1) encoding acyltransferase-like protein (Książkiewicz et al. 2017). As the LaAT gene expression was revealed to be correlated with total alkaloid content (Bunsupa et al. 2011), it was included in the marker array. When the LaAT was blasted against L. albus transcriptome, it tagged LAGI01_35805 and LAGI01_49436 as the most similar sequences. These transcripts were found to have high similarity to L. angustifolius Lup021586 and Lup021583 genes, annotated as encoding HXXXD-type acyltransferase family proteins. Analysis of the surrounding genes in the L. angustifolius assembly highlighted a Lup021589 (a bHLH35-like transcription factor) as a another hypothetical candidate for marker development. Mapping of the Lup021589 to the L. albus transcriptome resulted in the selection of LAGI01 54458. To summarize, the set of sequences used for pauper marker development consisted of TP16854, TP22150, TP30216, TP309728, TP447859, TP70046, LAGI01_35805, LAGI01_49436, and LAGI01_54458. 


\section{Development of PCR-based pauper molecular marker array}

For TP16854, TP22150, TP30216, TP309728, TP447859, and TP70046 sequences, markers were developed using those polymorphic loci which were published in the linkage map paper (Książkiewicz et al. 2017). Two dCAPS (TP16854_FD_R and TP70046_F_RD) and four CAPS (TP22150_F_R, TP30216_F_R, TP309728_F_R, TP447859_F_R) markers were designed. Mapping Kiev Mutant and P27174 reads (PRJNA380248) to the L. albus transcriptome revealed polymorphic loci in one exon in LAGI01_49436 and LAGI01_54458, and in two exons in LAGI01_35805. Three CAPS markers (LAGI01_35805_F1_R1, LAGI01_35805_F2_R2, LAGI01_49436_F2_R2) and one PCR-based INDEL marker (LAGI01_54458_F2_R1) were designed. Initial screening of white lupin lines with published PauperM1 marker (Lin et al. 2009) revealed high difficulty of inferring allele genotypes due to very small difference in product length and amplification of stutter bands. Therefore, this marker was transformed into a pair of CAPS markers exploiting two different polymorphic loci. The marker array was supplemented by two genebased markers, ESD4-F7 and ESD4-F8, which were recently developed for L. albus homolog of A. thaliana flowering induction pathway gene EARLY IN SHORT DAYS 4 (ESD4) and mapped very close to the pauper locus (Rychel et al. 2019). The list of developed markers with information on assigned $L$. angustifolius gene and genome sequences and L. albus transcripts is provided in Table 1. The list of primer pairs, PCR primer annealing temperature, enzyme used for polymorphism detection, and the lengths of restriction products for Kiev Mutant and P27174 lines are provided in Table 2.

\section{Linkage mapping of pauper markers}

The segregation of newly developed gene-based markers (LAGI01_49436_F2_R2, LAGI01_35805_F1_R1, LAGI01_35805_F2_R2, LAGI01_54458_F2_R1) was analyzed in the RIL population to provide data for linkage mapping. Markers PauperM1, TP16854, TP447859, TP22150, TP309728, TP70046, and TP30216 were already localized on the genetic map (Książkiewicz et al. 2017), however, with missing $14-53 \%$ of RIL genotyping data. To increase the quality of linkage mapping, the segregation of these markers was tested as well. Segregation data were obtained for $98.5 \%$ of RILs. All markers were localized in the linkage group ALB18 in the region carrying pauper locus. Both PauperM1 markers revealed identical segregation and localized $1.06 \mathrm{cM}$ upstream the pauper locus. Five markers (TP16854_FD_R, LAGI01_35805_F2_R2, LAGI01_35805_F1_R1,
LAGI01 49436 F2 R2, and LAGI01 54458 F2 R1) cosegregated with the pauper locus (Fig. 1). The linkage of these markers was confirmed by high-LOD values ( $\mathrm{min}$ 49.1, max 56.6, mean 55.25). Markers TP447859 F R, TP22150 F R, ESD4-F7, and ESD4-F8 formed a redundant cluster localized $0.79 \mathrm{cM}$ downstream the pauper locus. Markers TP309728 F R, TP70046 F RD, and TP30216 F R were mapped at further distances from the pauper, namely $1.06 \mathrm{cM}, 2.91 \mathrm{cM}$, and $7.70 \mathrm{cM}$. Information on marker $\chi^{2} P$ values for segregation distortion, position in linkage group, and LOD values is provided in Table 3. RIL segregation data is given in Supplementary File 2.

\section{Pauper marker validation in collection lines}

Validation set of lines contained 127 bitter and five pauper (Kiev Mutant, Boros, Lotos, Hansa, Kali), four exiguus (Start, Nelly USA, Butan, Tombowskij Skorospielyj), one nutricius (Nahrquell), and sixteen other sweet or intermediate accessions with unknown genotype according to the information obtained from the Plant Breeding Smolice Ltd., Co. (Dr. Stanisław Stawiński) and published data (Hackbarth 1957; Hackbarth 1961; Harrison and Williams 1982; Kroc et al. 2017; Porsche 1964; Šatović 1993; Troll 1958). Visualization of marker polymorphism for selected lines is provided in Supplementary File 3. Simple matching coefficients were calculated, to compare the marker genotype and the pauper phenotype. These values ranged from 0.15 to 0.94 , indicating rapid linkage disequilibrium decay around pauper locus. To address the putative applicability of newly developed markers in the marker-assisted selection, Rogers-Tanimoto coefficient values were calculated. Rogers-Tanimoto is a variant of the simple matching coefficient that gives double weight to mismatching variables, therefore accentuating false-positive and false-negative scores. Rogers-Tanimoto values were in the range from 0.08 to 0.88 . LAGI54458_F1 marker revealed to have identical simple matching and Rogers-Tanimoto values as the previously published PauperM1, namely 0.83 and 0.71 . LAGI01_35805_F1_R1 marker having those values as high as 0.94 and 0.88 was evidenced to be more applicable to marker-assisted selection than the PauperM1 (Table 4). All lines carrying pauper recessive alleles revealed positive LAGI01_35805_F1_R1 marker score. False-positive scores were obtained for four lines, namely 95015 "San Felices" (12.73\% alkaloid dry weight content), 95064 "Population-8062" (2.69\%), 95220 "FAM 120" (1.21\%), and 95023 "Oeiras-930/3" (4.93\%) (Kroc et al. 2017). All these lines are primitive accessions or landraces. Marker scores for the set of validation lines are provided in Supplementary File 4. 
Table 1 Sequences assigned to developed white lupin markers tagging pauper locus. Positions indicate the first nucleotide in the marker sequence alignment

\begin{tabular}{|c|c|c|c|c|c|c|}
\hline Marker & L. angustifolius chromosome & Position (nt) & L. angustifolius gene & Position (nt) & L. albus transcript & Position (nt) \\
\hline ESD4-F7 ${ }^{\mathrm{a}}$ & NLL-16 & 19043934 & Lup021600 & 1 & LAGI01_22606 & 1580 \\
\hline ESD4-F8 ${ }^{\mathrm{a}}$ & NLL-16 & 19043385 & Lup021600 & 417 & LAGI01_23187 & 1003 \\
\hline LAGI01_35805_F1_R1 & NLL-16 & 18720613 & Lup021586 & 2 & LAGI01_35805 & 149 \\
\hline LAGI01_35805_F2_R2 & NLL-16 & 18718376 & Lup021586 & 231 & LAGI01_35805 & 378 \\
\hline LAGI01_49436_F2_R2 & NLL-16 & 18680802 & Lup021583 & 804 & LAGI01_49436 & 71 \\
\hline LAGI01_54458_F2_R1 & NLL-16 & 18798603 & - & - & LAGI01_54458 & 538 \\
\hline PauperM1_F_R ${ }^{\mathrm{b}}$ & NLL-16 & 10380713 & - & - & - & - \\
\hline TP16854_FD_R & NLL-16 & 18718404 & Lup021586 & 730 & LAGI01_35805 & 880 \\
\hline TP22150_F_R & NLL-16 & 19032414 & Lup021599 & 1050 & LAGI01_34026 & 56 \\
\hline TP30216_F_R & NLL-16 & 9710799 & Lup030539 & 591 & LAGI01_22438 & 1175 \\
\hline TP309728_F_R & NLL-16 & 19185829 & Lup021606 & 773 & LAGI01_61485 & 673 \\
\hline TP447859_F_R & NLL-16 & 19092892 & Lup021602 & 389 & LAGI01_9900 & 557 \\
\hline TP70046_F_RD & NLL-19 & 15265260 & Lup026514 & 403 & LAGI01_45076 & 417 \\
\hline
\end{tabular}

${ }^{\text {a }}$ Marker published by (Rychel et al. 2019)

${ }^{\mathrm{b}}$ Marker published by (Lin et al. 2009)

Table 2 List of developed markers tagging pauper locus, with primer sequences, PCR primer annealing temperature, validated enzymes, and restriction product sizes

\begin{tabular}{|c|c|c|c|c|c|}
\hline Name & Primers & $\operatorname{PCR}\left({ }^{\circ} \mathrm{C}\right)$ & Validated enzyme & $\begin{array}{l}\text { Products } \\
\text { Kiev (bp) }\end{array}$ & $\begin{array}{l}\text { Products } \\
\text { P27174 (bp) }\end{array}$ \\
\hline TP16854_FD_R & $\begin{array}{l}\text { CAGCAAGAGATTCAAATGTTGTGAAAG } \\
\text { ATGAAGGAAATTAGTTGCAATGAATCAA }\end{array}$ & 60 & HindIII & 64 & 39,25 \\
\hline TP447859_F_R & $\begin{array}{l}\text { CTGCTTCTGATATTTTCAATGCATT } \\
\text { AAGCCATCAAATGCTTCAGAAGTAG }\end{array}$ & 60 & $M n l \mathrm{I}$ & 56,17 & 73 \\
\hline TP22150_F_R & $\begin{array}{l}\text { TTGCATGAGGGAAGATGGACG } \\
\text { ATAGCATGTGACCTGGAGGAC }\end{array}$ & 60 & $M n l \mathrm{I}$ & $81,48,25,8$ & $129,25,8$ \\
\hline TP309728_F_R & $\begin{array}{l}\text { TTGAAGGTCTACAAAGGCATCC } \\
\text { TATAGACCAGCACAACCCTCTG }\end{array}$ & 60 & $\operatorname{Taq} \mathrm{I}$ & 75,40 & 115 \\
\hline TP70046_F_RD & $\begin{array}{l}\text { CCATCATTCCTGCCATAAGG } \\
\text { ATCAAGGAAGAGTTAGAGAAT }\end{array}$ & 60 & HinfI & 110,21 & 131 \\
\hline TP30216_F_R & $\begin{array}{l}\text { TATTAAGTCGATTTGGTGGAGCT } \\
\text { AATACATGAAATAGGCCCAATGAAA }\end{array}$ & 56 & HinfI & 76,34 & 110 \\
\hline LAGI01_49436_F2_R2 & $\begin{array}{l}\text { CTCTGAACTTGGGCATGGATG } \\
\text { ACTTGGTGCCTATGTATGGAGA }\end{array}$ & 64 & BamHI & 464,66 & 527 \\
\hline LAGI01_35805_F1_R1 & $\begin{array}{l}\text { TGGCATCACTGAAAATTGAGATGA } \\
\text { CTTTGAGAGGGCTTGTTTGAG }\end{array}$ & 64 & $B c l I$ & 197 & 108,89 \\
\hline LAGI01_35805_F2_R2 & $\begin{array}{l}\text { GCTAGTAAAACAACCCAACGGA } \\
\text { GCCCTAGCTCTTGATCTCCAG }\end{array}$ & 64 & $M b o \mathrm{I}$ & $253,216,109,16$ & $362,216,16$ \\
\hline LAGI01_54458_F2_R1 & $\begin{array}{l}\text { AAAAGTGTTAGAAAAGTACAGCAC } \\
\text { CAGTGACTCCAACAAAAGCACA }\end{array}$ & 52 & - & 108 & 98 \\
\hline ESD4-F8 ${ }^{\mathrm{a}}$ & $\begin{array}{l}\text { CTGCGCTTCTCCTGTAGTTCAATTT } \\
\text { AGACCTTGAAACCGATAGTCATAATAG }\end{array}$ & 63 & MseI & 351 & 178,173 \\
\hline ESD4-F7 ${ }^{\mathrm{a}}$ & $\begin{array}{l}\text { CCCTAACCAACGGTAGCTTGATAT } \\
\text { TGTGCTTTTTCACCCCTCTC }\end{array}$ & 52 & EcoRV & 232,22 & 254 \\
\hline PauperM1_F_R_HhaI ${ }^{\mathrm{b}}$ & $\begin{array}{l}\text { AAGAAAAGGCCCAATG } \\
\text { TTTTAAAGTCATACCATTGAG }\end{array}$ & 54 & HhaI & $\sim 209$ & 108,99 \\
\hline PauperM1_F_R_Hinfl ${ }^{\mathrm{b}}$ & $\begin{array}{l}\text { AAGAAAAGGCCCAATG } \\
\text { TTTTAAAGTCATACCATTGAG }\end{array}$ & 54 & HinfI & $145, \sim 64$ & 207 \\
\hline
\end{tabular}

${ }^{\text {a }}$ Marker published by (Rychel et al. 2019)

${ }^{\mathrm{b}}$ Improvement of the PauperM1 marker published by (Lin et al. 2009) 


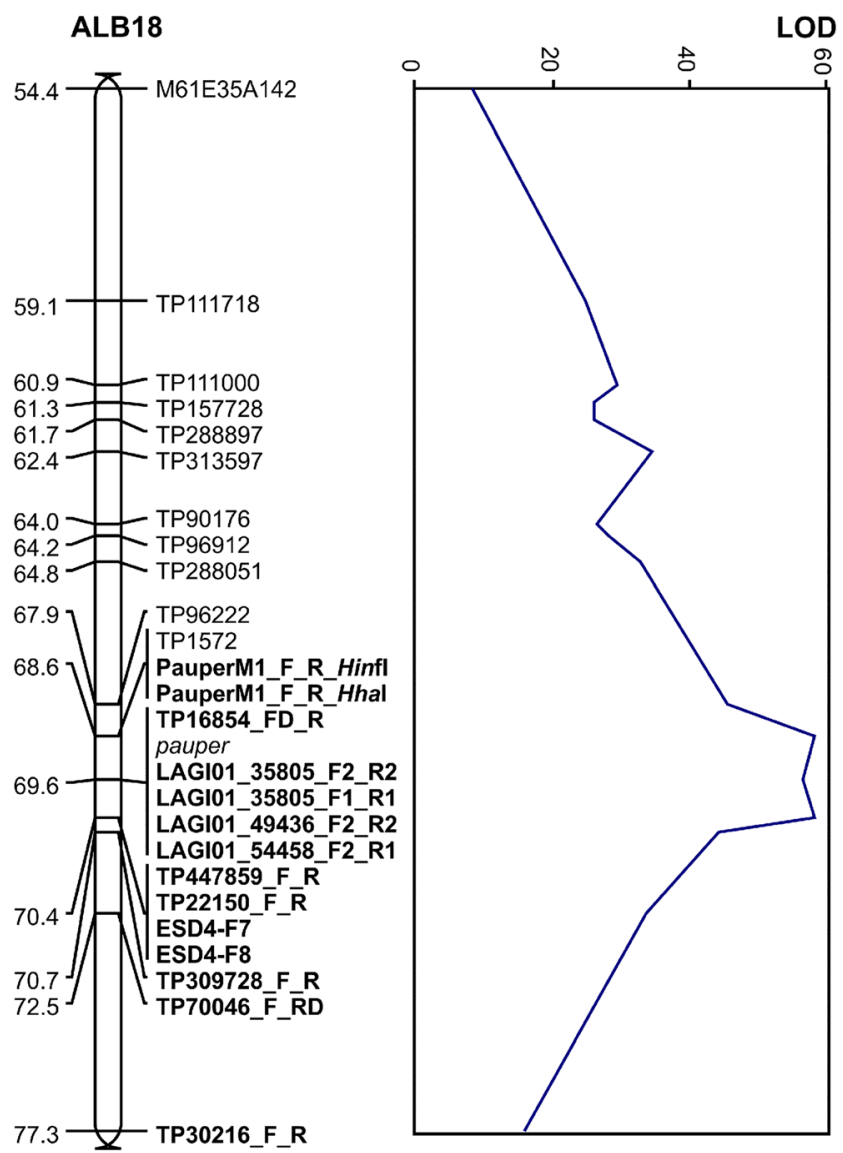

Fig. 1 Localization of markers in the white lupin linkage group ALB18 region carrying pauper locus. Vertical bar graph visualizes linkage group fragment with cumulative genetic distance scale expressed in centimorgans $(\mathrm{cM})$. The linear plot shows corresponding LOD values of linkage to adjacent markers. Names of markers analyzed in this study are in boldface

\section{Discussion}

\section{Exploitation of shared synteny for genetic studies in legumes}

In the present study, the synteny-based approach was applied to design molecular markers delimiting the pauper locus. The concept of exploitation of genome collinearity to transfer information from model plants to crop species emerged soon after sequencing the first three legume species (Cannon et al. 2009; Mudge et al. 2005). One of the first examples was positional cloning of a legume symbiosis LjSym 2 gene based on the comparative mapping between the three genomes differing by the advancement of molecular tools developed, namely Lotus japonicus (linkage map and contigs of transformation-competent artificial chromosomes), Pisum sativum (linkage map), and A. thaliana (chromosome-scale genome assembly) (Stracke et al. 2004). The sequence of A. thaliana genome revealed to be beneficial in mapping candidate genes conferring important agronomic domestication traits, growth determination, and photoperiod sensitivity, in common bean (Kwak et al. 2008). Molecular and comparative mapping combined with classical genetic approach was successfully applied to decipher the gene underlying yellow/ green cotyledon polymorphism, which was first reported by Gregor Mendel in 1866 (Armstead et al. 2007). In the early years of legume comparative genomic studies, map-based cloning strategy resulted in the identification of the $R C T 1$, an $M$. truncatula resistance gene that confers the multi-race resistance of alfalfa to a hemibiotrophic fungal pathogen Colletotrichum trifolii, causing anthracnose disease (Yang et al. 2008b). Progress in legume genome sequencing provided novel evidence for large-scale synteny existing between the papilionoid subclades which diverged about 50 million years ago (Bertioli et al. 2009). When the genome assemblies of $M$. truncatula and L. japonicus were aligned to the linkage map of Phaseolus vulgaris, novel large-scale macrosyntenic blocks were identified, justifying the concept of cross-species comparisons for tracking particular domestication genes (McConnell et al. 2010). As an example, a candidate gene for the hypernodulation mutation $\operatorname{nod} 3$ in pea was elucidated by the comparative mapping to $M$. truncatula genome carrying a nodulation regulation $P u b 1$ gene in the syntenic region (Bordat et al. 2011). To facilitate studies involving genome sequence comparisons and synteny-based gene annotation, a LegumeIP 2.0 platform hosting large-scale genomic/ transcriptomic data and integrative tools for bioinformatic analysis has been launched ( $\mathrm{Li}$ et al. 2012a; Li et al. 2016). The reconstruction of a comparative map composed of seven species from the galegoid clade (M. truncatula, M. sativa, Lens culinaris, P. sativum, L. japonicus, Cicer arietinum, Vicia $f a b a$ ) and three species from the phaseoloid clade (Vigna radiata, P. vulgaris, Glycine max) carrying crossspecies gene-derived markers revealed numerous macrosyntenic segments shared between all species analyzed (Lee et al. 2017). Recently, ten sequenced legume genomes were hierarchically aligned to establish a family-level genomics platform for studying evolutionary changes as well as functional analysis of genes involved in regulatory pathways (Wang et al. 2017).

Among lupins, L. angustifolius was the first species subjected to genetic map development and physical mapping studies (Boersma et al. 2005; Kaczmarek et al. 2009; Kasprzak et al. 2006; Kruszka and Wolko 1999; Leśniewska et al. 2011; Nelson et al. 2006). Comparative mapping of the progressively improved versions of L. angustifolius linkage map to sequence legume genomes revealed multiple blocks of conserved synteny carrying gene-rich regions and some candidate domestication genes (Kamphuis et al. 2015; Kroc et al. 2014; Książkiewicz et al. 2016; Książkiewicz et al. 2013; Książkiewicz et al. 2015; Nelson et al. 2010; Nelson et al. 2006; Przysiecka et al. 2015; Wyrwa et al. 2016). The synteny-based 
Table 3 RIL segregation data, chi-square $P$ values for segregation distortion, linkage group positions, and LOD scores to adjacent loci calculated for white lupin pauper markers

\begin{tabular}{|c|c|c|c|c|c|}
\hline Name & $\%$ RIL data & $\begin{array}{l}\chi^{2} \\
P \text { value }\end{array}$ & Linkage group & Locus $(\mathrm{cM})$ & LOD scores \\
\hline PauperM1_F_R_HhaI & 99.0 & 0.75 & ALB18 & 68.57 & $52.7,58.1$ \\
\hline PauperM1_F_R_HinfI & 99.0 & 0.75 & ALB18 & 68.57 & $58.1,49.1$ \\
\hline pauper $^{\mathrm{a}}$ & 95.4 & 0.66 & ALB18 & 69.64 & $55.4,54.8$ \\
\hline LAGI01_49436_F2_R2 & 96.4 & 0.76 & ALB18 & 69.64 & $56.3,56.3$ \\
\hline TP16854_FD_R & 99.0 & 0.83 & ALB18 & 69.64 & $49.1,55.4$ \\
\hline LAGI01_35805_F2_R2 & 97.4 & 0.78 & ALB18 & 69.64 & $54.8,56.6$ \\
\hline LAGI01_35805_F1_R1 & 98.0 & 0.71 & ALB18 & 69.64 & $56.6,56.3$ \\
\hline LAGI01_54458_F2_R1 & 98.0 & 0.83 & ALB18 & 69.64 & $56.3,54.8$ \\
\hline TP22150_F_R & 99.5 & 0.78 & ALB18 & 70.43 & $58.1,58.4$ \\
\hline ESD4-F7 & 99.5 & 0.78 & ALB18 & 70.43 & $58.4,58.4$ \\
\hline ESD4-F8 & 99.5 & 0.78 & ALB18 & 70.43 & $58.4,55.1$ \\
\hline TP447859_F_R & 99.0 & 0.83 & ALB18 & 70.43 & $54.8,58.1$ \\
\hline TP309728_F_R & 98.5 & 0.78 & ALB18 & 70.69 & $55.1,44.2$ \\
\hline TP70046_F_RD & 96.4 & 0.83 & ALB18 & 72.55 & $44.2,33.6$ \\
\hline TP30216_F_R & 99.5 & 0.25 & ALB18 & 77.34 & $33.6,16.0$ \\
\hline
\end{tabular}

${ }^{a}$ Locus published by (Książkiewicz et al. 2017; Phan et al. 2007)

approach was further exploited to identify the particular gene (LanFTc1, a homolog of A. thaliana FLOWERING LOCUS T) underlying one of the major domestication loci in L. angustifolius, $K u$, conferring vernalization independence and early flowering (Nelson et al. 2017; Nelson et al. 2006). Even the mechanism of regulation, based on the relatively long insertion/deletions in the promoter sequence was revealed to be conserved (Liu et al. 2014; Taylor et al. 2019). The pattern of cross-species synteny facilitated also the assembly of the L. angustifolius pseudochromosomes, providing anchors for scaffold order and orientation in the regions where the marker resolution was insufficient due to low recombination rate (Hane et al. 2017). This assembly has been further improved with the aid of an ultra-high-density genetic map containing 34574 sequence-defined markers (Zhou et al. 2018).

Molecular studies on white lupin based on comparative mapping approaches have been hampered for many years

Table 4 Validation of pauper markers in white lupin collection lines differing in alkaloid content

\begin{tabular}{|c|c|c|c|c|}
\hline Marker & $\begin{array}{l}\text { Simple matching coefficient } \\
\text { with bitter/sweet score }\end{array}$ & $\begin{array}{l}\text { Rogers-Tanimoto coefficient } \\
\text { with bitter/sweet score }\end{array}$ & $\begin{array}{l}\text { Correlation with } \\
\text { bitter/sweet score }\end{array}$ & $\begin{array}{l}\text { Correlation with } \% \\
\text { alkaloid content }\end{array}$ \\
\hline LAGI01_35805_F1_R1 & 0.94 & 0.88 & 0.71 & 0.26 \\
\hline LAGI01_54458_F2_R1 & 0.83 & 0.71 & 0.41 & 0.15 \\
\hline PauperM1_F_R_HhaI & 0.83 & 0.71 & 0.45 & 0.15 \\
\hline PauperM1_F_R_HinfI & 0.83 & 0.71 & 0.45 & 0.15 \\
\hline TP70046_F_RD & 0.68 & 0.52 & 0.33 & 0.27 \\
\hline TP16854_FD_R & 0.64 & 0.47 & 0.34 & 0.31 \\
\hline TP30216_F_R & 0.52 & 0.35 & 0.18 & 0.09 \\
\hline TP309728_F_R & 0.49 & 0.33 & 0.09 & 0.02 \\
\hline TP447859_F_R & 0.47 & 0.30 & 0.07 & 0.06 \\
\hline LAGI01_35805_F2_R2 & 0.45 & 0.29 & 0.25 & 0.26 \\
\hline LAGI01_49436_F2_R2 & 0.31 & 0.18 & 0.17 & 0.16 \\
\hline TP22150_F_R & 0.18 & 0.10 & 0.03 & -0.05 \\
\hline ESD4-F8 & 0.15 & 0.08 & 0.05 & -0.01 \\
\hline ESD4-F7 & 0.15 & 0.08 & 0.05 & -0.01 \\
\hline
\end{tabular}


because the published linkage maps carried a relatively small number of sequenced markers (Croxford et al. 2008; Phan et al. 2007; Vipin et al. 2013). The most recent linkage map of white lupin with 3669 sequenced markers highlighted the collinearity between L. angustifolius and L. albus genomes and provided novel possibilities for map-based gene cloning (Książkiewicz et al. 2017). This tool was further exploited to identify candidate genes involved in white lupin early flowering (Rychel et al. 2019). The information on highly conserved synteny between L. albus and L. angustifolius genomes was also harnessed in the present study to design new markers tagging low alkaloid pauper locus.

\section{Markers and genes for low alkaloid content in lupins}

Alkaloid content as a major potentially toxic anti-nutritional factor was thoroughly investigated during the lupin domestication process, and numerous low alkaloid accessions were selected in all three crop Old World lupin species: L. angustifolius, L. albus, and L. luteus (Hackbarth 1957; Hackbarth 1961; Hackbarth and Troll 1956; Święcicki 1986; Święcicki and Jach 1980; Święcicki and Święcicki 1995). Significant progress in the determination of low alkaloid lines has been also achieved in the main New World lupin crop, L. mutabilis (Galek et al. 2017). Among lupins, L. angustifolius has been subjected to the most advanced studies on genetic and molecular factors affecting quinolizidine alkaloid biosynthesis. Three major recessive low-alkaloid alleles were identified in L. angustifolius germplasm, namely iucundus, depressus, and esculentus; however, only iucundus was widely introduced into breeding programs (Święcicki and Święcicki 1995). L. angustifolius RIL mapping population developed from the cross of 83A:476 (maternal, sweet, domesticated) and P27255 (paternal, bitter, wild) enabled genetic localization of iucundus locus. However, this trait revealed high distortion from the expected 1:1 segregation ratio, evidenced by the chi-square $P$ value of 0.008 (Boersma et al. 2005). Iucundus was localized in all versions of the L. angustifolius linkage map but was surrounded only by MFLP-derived markers lacking sequence information (Boersma et al. 2005; Kamphuis et al. 2015; Nelson et al. 2010). To provide a DNA marker tightly linked to iucundus $(\sim 0.9 \mathrm{cM})$, a separate study was performed involving 20 lines and 320 MFLP fingerprints (Li et al. 2011). Novel markers closely related to the iucundus were developed during genome sequencing attempts; however, no candidate gene was hypothesized (Hane et al. 2017; Zhou et al. 2018). Recently, transcriptome-based studies revealed high correlation of alkaloid content with leaf tissue expression levels of genes encoding lysine/ornithine decarboxylase $(L a L / O D C)$, copper amine oxidase $(L a C A O)$, acyltransferase $(L a A T)$, berberine bridge enzyme ( $L a B B E$-like), and major latex-like proteins
(LaMLP1-like, LaMLP2-like, and LAMLP4-like) (Frick et al. 2018; Yang et al. 2017). The group of L. angustifolius quinolizidine alkaloid biosynthesis genes is putatively regulated by an APETALA2/ethylene responsive transcription factor, which was evidenced by linkage mapping and transcriptome profiling as a strong candidate for iucundus (Kroc et al. 2019).

In L. luteus, four low-alkaloid alleles were identified, including dulcis, amoenus, liber (von Sengbusch 1942), and $v$ (Gustafsson and Gadd 1965). Forms with alkaloid content below $0.05 \%$ were developed (Święcicki and Jach 1980). Molecular resources for this species are very limited and include two transcriptome assemblies derived from independent studies and the set of insertion/deletion markers developed by next-generation sequencing of genomic reduction libraries (Glazinska et al. 2017; Osorio et al. 2018; Parra-González et al. 2012). The lack of mapping populations and linkage maps considerably impeded research on genes underlying low alkaloid content in this species.

Genetic studies involving L. albus germplasm resulted in the identification of several loci underlying low alkaloid content: pauper/primus/tercius, exiguus, nutricius, mitis, suavis, reductus, and minutus (Hackbarth 1957; Hackbarth 1961; Harrison and Williams 1982; Porsche 1964; Šatović 1993; Troll 1958). Pauper was widely exploited for breeding; exiguus and nutricius were used occasionally, whereas other loci remained untapped (Harrison and Williams 1982; Šatović 1993). First two linkage maps addressing pauper segregation did not provide any marker closely related to this gene (Phan et al. 2007; Vipin et al. 2013). With the aid of the MFLP technique, a PCR-based PauperM1 marker tagging pauper locus by $1.4 \mathrm{cM}$ was developed (Lin et al. 2009). However, due to the small length difference between the alleles and the production of some background stutter bands, analysis of this marker required tedious and time-consuming sequencing gel electrophoresis.

\section{A step towards identification of the gene underlying pauper locus}

In this paper, the PauperM1 marker was improved to a CAPS marker addressing two closely located SNPs, recognized by two different enzymes. Enzyme HhaI is expected to cut the bitter allele, whereas Hinfl-the sweet one. Such an approach minimizes the risk of false-positive and false-negative scores resulting from non-occurrence of cleavage due to reaction preparation issues. In the present study, six SNP markers generated by genotyping-by-sequencing (Książkiewicz et al. 2017) were transformed to PCR-based markers using CAPS and dCAPS approaches (Konieczny and Ausubel 1993; Neff et al. 1998). It is widely adapted strategy for scoring SNP markers obtained by high-throughput sequencing (Shavrukov 2016). Several tools were developed, allowing 
design of CAPS and/or dCAPS markers on one-by-one basis (dCAPS Finder, BlastDigester, SNP2CAPS, SGN CAPS Designer) or as a high-throughput automated process (CAPS/dCAPS Designer) (Ilic et al. 2004; Li et al. 2018; Neff et al. 2002; Thiel et al. 2004). For routine implementation, other PCR allelic discrimination technologies are considered, including rhAmp, TaqMan, or KASP assays (Broccanello et al. 2018). Indeed, a Fluidigm nanofluidic array genotyping platform has been exploited to formulate L. angustifolius SNP array and provide markers for linkage mapping and genome assembly (Hane et al. 2017; Kamphuis et al. 2015; Yang et al. 2013; Zhou et al. 2018).

One of the newly developed markers, LAGI01_35805_F1_R1, was revealed to have higher applicability for pauper marker-assisted selection than the previously published PauperM1 marker (Lin et al. 2009), evidenced by higher values of all coefficients calculated (simple matching, Rogers-Tonimoto, Pearson product-moment correlation). However, false-positive scores were revealed for four lines (constituting $2.5 \%$ of analyzed plant materials). All these lines were primitive accessions or landraces, including a line with the highest dry weight seed alkaloid content in the collection, 95015 "San Felices" (Kroc et al. 2017). Such an observation may indicate that the pauper locus gene is different than the gene represented by the LAGI01_35805_F1_R1 marker sequence. It is also possible that the LAGI01_35805 is derived from the true pauper locus gene but the SNP recognized by this marker is not the functional mutation causing low alkaloid content. LAGI01_35805 is a homolog of L. angustifolius Lup021586 gene, annotated as the LaAT gene (AB581532.1) (Książkiewicz et al. 2017). LaAT is a representative of BAHD acyl-CoA-dependent acyltransferase superfamily and was shown to be highly expressed in the leaves of quinolizidine alkaloid-producing L. angustifolius plants but undetectable in the sweet ones (Bunsupa et al. 2011). However, in L. angustifolius, the function of low alkaloid iucundus gene is assigned rather to a regulatory agent (a transcription factor) than to an enzyme directly involved in alkaloid biosynthesis (Kroc et al. 2019). Nevertheless, L. angustifolius and L. albus have a relatively different pattern of alkaloid compound variation and partially differ by major component influencing total alkaloid content (Boschin et al. 2008; Kamel et al. 2016; Kroc et al. 2017). It was suggested that functions of iucundus and pauper genes may be distinct because these species have different lysine profiles among wild and sweet accessions (Frick et al. 2017). As expected, negative LAGI01 35805 F1 R1 scores were obtained for four low alkaloid lines carrying exiguus gene (95422 "Start", 95480 "Nelly", 95513 "Butan" derived from Start $\times$ Wat, 95454 "Tombowskij Skorospielyj") and one carrying nutricius gene (95509 "Nahrquell") (Hackbarth 1957; Hackbarth 1961; Harrison and Williams 1982; Porsche 1964; Šatović 1993; Troll 1958; Stawiński S. unpublished).
Additionally, negative LAGI01_35805_F1_R1 scores were revealed for six sweet lines with unknown low-alkaloid donor (95175 “R-84141”, 95433 "Dniepr”, 95160 "R-243”, 95166 "SF-479”, 95445 "Lutrop," and 95449 "Buttercup"). These lines may carry exiguus, nutricius, or other low-alkaloid genes.

In the sister crop species, narrow-leafed lupin, the breeding process has been considerably facilitated by markers which were developed to select key agronomic traits and subsequently implemented in Australian breeding programs. These include early flowering (KuHM1, LanFTc1_INDEL) (Boersma et al. 2007a; Nelson et al. 2017), reduced pod shattering (TaLi, TaM1, TaM2, LeM1, LeM2, LeLi) (Boersma et al. 2007b; Boersma et al. 2009; Li et al. 2010; Li et al. 2012c), low alkaloid profile (iucLi) (Li et al. 2011), soft seediness (marker MoLi) (Li et al. 2012b), and resistance to diseases caused by pathogenic fungi, including anthracnose (AntjM1, AntjM2, AnManM1) (Yang et al. 2004; Yang et al. 2008a; You et al. 2005) and Phomopsis stem blight (PhtjM1, PhtjM2, Ph258M1, Ph258M2) (Yang et al. 2002). Numerous studies revealed that the further improvement of white lupin as a crop will require incorporation of rare alleles, such as resistance to anthracnose found only in Ethiopian lines, from wild landraces which are bitter and late flowering (Adhikari et al. 2009; Adhikari et al. 2013; Phan et al. 2007). Reselection of agronomic traits in the progeny could be greatly facilitated by the use of markers targeting particular domestication genes. Such a model was established for the narrow-leafed lupin (Cowling et al. 2009). Markers for low alkaloid pauper locus developed in this study, together with those recently published for early flowering (Rychel et al. 2019), address this requirement and constitute a versatile array for white lupin molecular breeding.

Acknowledgments We thank Prof. Paolo Annicchiarico and Dr. Nelson Nazzicari from CREA-FLC, Council for Agricultural Research and Economics, Research Centre for Fodder Crops and Dairy Production (Lodi, Italy), for early access to L. albus genotyping-by-sequencing data (Książkiewicz et al. 2017). We thank the Department of Agriculture and Food of Western Australia (Perth, Australia) for the seeds of Kiev Mutant $\times$ P27174 mapping population. We thank Poznan Plant Breeding Ltd. station located in Wiatrowo for the seeds of white lupin lines for pauper marker genotyping assay. We also thank Dr. Matthew Nelson from the Commonwealth Science and Industry Research Organisation (Wembley, Western Australia, Australia) for pre-publication access to the white lupin transcriptome data (SRX2663946 and SRX2663947).

Author's contribution SR performed all experimental procedures (plant cultivation, DNA isolation, PCR, restriction enzyme cleavage, agarose gel electrophoresis) and prepared result files with genotyping data. MK designed molecular markers, performed linkage mapping and other calculations, and drafted the manuscript.

Funding This research was funded by the European Community's Seventh Framework Programme LEGATO project (FP7-613551). 


\section{Compliance with ethical standards}

This article does not contain any studies with human participants or animals, performed by any of the authors.

Conflict of interest The authors declare that they have no conflict of interest.

Data availability All data generated during this study are included in this published article and its supplementary information files. Marker sequences were deposited in the DNA Data Bank of Japan (accession numbers LC466085-LC466106).

Open Access This article is distributed under the terms of the Creative Commons Attribution 4.0 International License (http:// creativecommons.org/licenses/by/4.0/), which permits unrestricted use, distribution, and reproduction in any medium, provided you give appropriate credit to the original author(s) and the source, provide a link to the Creative Commons license, and indicate if changes were made.

\section{References}

Adhikari KN, Buirchell BJ, Thomas GJ, Sweetingham MW, Yang H (2009) Identification of anthracnose resistance in Lupinus albus L. and its transfer from landraces to modern cultivars. Crop Pasture Sci 60:472-479. https://doi.org/10.1071/CP08092

Adhikari KN, Thomas G, Diepeveen D, Trethowan R (2013) Overcoming the barriers of combining early flowering and anthracnose resistance in white lupin (Lupinus albus L.) for the Northern Agricultural Region of Western Australia. Crop Pasture Sci 64:914 921. https://doi.org/10.1071/CP13249

Altschul SF, Gish W, Miller W, Myers EW, Lipman DJ (1990) Basic local alignment search tool. J Mol Biol 215:403-410. https://doi.org/10. 1016/S0022-2836(05)80360-2

Armstead I et al (2007) Cross-species identification of Mendel's I locus. Science 315:73. https://doi.org/10.1126/science.1132912

Arnoldi A, Greco S (2011) Nutritional and nutraceutical characteristics of lupin protein. Nutrafoods 10:23-29. https://doi.org/10.1007/ bf03223356

Bertioli DJ et al (2009) An analysis of synteny of Arachis with Lotus and Medicago sheds new light on the structure, stability and evolution of legume genomes. BMC Genomics 10:45. https://doi.org/10.1186/ 1471-2164-10-45

Boersma JG, Buirchell BJ, Sivasithamparam K, Yang H (2007a) Development of a sequence-specific PCR marker linked to the $K u$ gene which removes the vernalization requirement in narrow-leafed lupin. Plant Breed 126:306-309. https://doi.org/10.1111/j.14390523.2007.01347.x

Boersma JG, Buirchell BJ, Sivasithamparam K, Yang H (2007b) Development of two sequence-specific PCR markers linked to the le gene that reduces pod shattering in narrow-leafed lupin (Lupinus angustifolius L). Genet Mol Biol 30:623-629. https://doi.org/10. 1590/S1415-47572007000400020

Boersma JG, Nelson MN, Sivasithamparam K, Yang Ha (2009) Development of sequence-specific PCR markers linked to the Tardus gene that reduces pod shattering in narrow-leafed lupin (Lupinus angustifolius L). Mol Breed 23:259-267. https://doi.org/ 10.1007/s11032-008-9230-2

Boersma JG, Pallotta M, Li C, Buirchell BJ, Sivasithamparam K, Yang H (2005) Construction of a genetic linkage map using MFLP and identification of molecular markers linked to domestication genes in narrow-leafed lupin (Lupinus angustifolius L). Cell Mol Biol Lett 10:331-344

Bordat A et al (2011) Translational genomics in legumes allowed placing in silico 5460 Unigenes on the pea functional map and identified candidate genes in Pisum sativum L. G3: Genes|Genomes|Genetics 1:93-103. https://doi.org/10.1534/g3.111.000349

Boschin G, Annicchiarico P, Resta D, D'Agostina A, Arnoldi A (2008) Quinolizidine alkaloids in seeds of lupin genotypes of different origins. J Agric Food Chem 56:3657-3663. https://doi.org/10.1021/ jf7037218

Boschin G, D'Agostina A, Annicchiarico P, Arnoldi A (2007) The fatty acid composition of the oil from Lupinus albus cv. Luxe as affected by environmental and agricultural factors. Eur Food Res Technol 225:769-776. https://doi.org/10.1007/s00217-006-0480-0

Broccanello C, Chiodi C, Funk A, McGrath JM, Panella L, Stevanato P (2018) Comparison of three PCR-based assays for SNP genotyping in plants. Plant Methods 14:28. https://doi.org/10.1186/s13007-0180295-6

Bunsupa S, Okada T, Saito K, Yamazaki M (2011) An acyltransferaselike gene obtained by differential gene expression profiles of quinolizidine alkaloid-producing and nonproducing cultivars of Lupinus angustifolius. Plant Biotechnol 28:89-94. https://doi.org/ 10.5511/plantbiotechnology.10.1109b

Cannon SB, May GD, Jackson SA (2009) Three sequenced legume genomes and many crop species: rich opportunities for translational genomics. Plant Physiol 151:970-977. https://doi.org/10.1104/pp. 109.144659

Cowling WA, Buirchell BJ, Falk DE (2009) A model for incorporating novel alleles from the primary gene pool into elite crop breeding programs while reselecting major genes for domestication or adaptation. Crop Pasture Sci 60:1009-1015. https://doi.org/10.1071/ CP08223

Croxford AE, Rogers T, Caligari PDS, Wilkinson MJ (2008) Highresolution melt analysis to identify and map sequence-tagged site anchor points onto linkage maps: a white lupin (Lupinus albus) map as an exemplar. New Phytol 180:594-607. https://doi.org/10.1111/j. 1469-8137.2008.02588.x

Darling AC, Mau B, Blattner FR, Perna NT (2004) Mauve: multiple alignment of conserved genomic sequence with rearrangements. Genome Res 14:1394-1403. https://doi.org/10.1101/gr.2289704

Daverio M, Cavicchiolo ME, Grotto P, Lonati D, Cananzi M, Da Dalt L (2014) Bitter lupine beans ingestion in a child: a disregarded cause of acute anticholinergic toxicity. Eur J Pediatr 173:1549-1551. https://doi.org/10.1007/s00431-013-2088-2

Frick KM, Foley RC, Kamphuis LG, Siddique KHM, Garg G, Singh KB (2018) Characterization of the genetic factors affecting quinolizidine alkaloid biosynthesis and its response to abiotic stress in narrowleafed lupin (Lupinus angustifolius L.). Plant Cell Environ 41:21552168. https://doi.org/10.1111/pce.13172

Frick KM, Kamphuis LG, Siddique KH, Singh KB, Foley RC (2017) Quinolizidine alkaloid biosynthesis in lupins and prospects for grain quality improvement. Front Plant Sci 8:87. https://doi.org/10.3389/ fpls.2017.00087

Galek R, Sawicka-Sienkiewicz E, Zalewski D, Stawiński S, Spychała K (2017) Searching for low alkaloid forms in the Andean lupin (Lupinus mutabilis) collection. Czech J Genet Plant Breed 53:5562. https://doi.org/10.17221/71/2016-CJGPB

Gladstones JS (1970) Lupins as crop plants. Field Crop Abstracts 23:26

Glazinska P et al (2017) De novo transcriptome profiling of flowers, flower pedicels and pods of Lupinus luteus (yellow lupine) reveals complex expression changes during organ abscission. Front Plant Sci 8:641. https://doi.org/10.3389/fpls.2017.00641

Gustafsson A, Gadd I (1965) Mutations and crop improvement. II The genus Lupinus (Leguminosae). Hereditas 53:15-39

Hackbarth J (1957) Die Gene der Lupinenarten. III Weiße Lupine (Lupinus albus). Zeitschrift für Pflanzenzüchtung 37:185-191 
Hackbarth J (1961) Untersuchungen über die Vererbung der Alkaloidarmut bei der Weiss-lupine (Lupinus albus). Zeitschrift für Pflanzenzüchtung 45:334-344

Hackbarth J, Troll HJ (1956) Die Lupinen als Körnerleguminosen und Futterpflanzen. In: Handbuch der Pflanzenzüchtung. Verlag Paul Parey, Berlin, pp 1-51

Hane JK et al (2017) A comprehensive draft genome sequence for lupin (Lupinus angustifolius), an emerging health food: insights into plant-microbe interactions and legume evolution. Plant Biotechnol J 15:318-330. https://doi.org/10.1111/pbi.12615

Harrison JEM, Williams W (1982) Genetical control of alkaloids in Lupinus albus. Euphytica 31:357-364. https://doi.org/10.1007/ bf00021651

Ilic K, Berleth T, Provart NJ (2004) BlastDigester-a web-based program for efficient CAPS marker design. Trends Genet 20:280-283. https://doi.org/10.1016/j.tig.2004.04.012

Kaczmarek A, Naganowska B, Wolko B (2009) Karyotyping of the narrow-leafed lupin (Lupinus angustifolius L.) by using FISH, PRINS and computer measurements of chromosomes. J Appl Genet 50:77-82. https://doi.org/10.1007/BF03195657

Kamel KA, Święcicki W, Kaczmarek Z, Barzyk P (2016) Quantitative and qualitative content of alkaloids in seeds of a narrow-leafed lupin (Lupinus angustifolius L.) collection. Genet Resour Crop Evol 63: 711-719. https://doi.org/10.1007/s10722-015-0278-7

Kamphuis LG, Hane JK, Nelson MN, Gao L, Atkins CA, Singh KB (2015) Transcriptome sequencing of different narrow-leafed lupin tissue types provides a comprehensive uni-gene assembly and extensive gene-based molecular markers. Plant Biotechnol J 13:14-25. https://doi.org/10.1111/pbi.12229

Kasprzak A, Safár J, Janda J, Dolezel J, Wolko B, Naganowska B (2006) The bacterial artificial chromosome (BAC) library of the narrowleafed lupin (Lupinus angustifolius L). Cell Mol Biol Lett 11:396407. https://doi.org/10.2478/s11658-006-0033-3

Kearse $M$ et al (2012) Geneious basic: an integrated and extendable desktop software platform for the organization and analysis of sequence data. Bioinformatics 28:1647-1649. https://doi.org/10.1093/ bioinformatics/bts 199

Konieczny A, Ausubel FM (1993) A procedure for mapping Arabidopsis mutations using co-dominant ecotype-specific PCR-based markers. Plant J 4:403-410. https://doi.org/10.1046/j.1365-313X.1993. 04020403.x

Kroc M et al (2019) Transcriptome-derived investigation of biosynthesis of quinolizidine alkaloids in narrow-leafed lupin (Lupinus angustifolius L.) highlights candidate genes linked to iucundus locus. Sci Rep 9:2231. https://doi.org/10.1038/s41598-018-37701-5

Kroc M, Koczyk G, Święcicki W, Kilian A, Nelson MN (2014) New evidence of ancestral polyploidy in the Genistoid legume Lupinus angustifolius L. (narrow-leafed lupin). Theor Appl Genet 127:12371249. https://doi.org/10.1007/s00122-014-2294-y

Kroc M, Rybiński W, Wilczura P, Kamel K, Kaczmarek Z, Barzyk P, Święcicki W (2017) Quantitative and qualitative analysis of alkaloids composition in the seeds of a white lupin (Lupinus albus L.) collection. Genet Resour Crop Evol 64:1853-1860. https://doi.org/ 10.1007/s10722-016-0473-1

Kruszka K, Wolko B (1999) Linkage maps of morphological and molecular markers in lupin. In: van Santen E, Wink M, Weissmann S, Roemer P (eds) 9th international lupin conference, Klink/Müritz, Germany, 1999. International Lupin Association, Canterbury, New Zealand, pp 100-106

Książkiewicz M et al. (2017) A high-density consensus linkage map of white lupin highlights synteny with narrow-leafed lupin and provides markers tagging key agronomic traits. Sci Rep 7:15335. https://doi.org/10.1038/s41598-017-15625-w

Książkiewicz M, Rychel S, Nelson MN, Wyrwa K, Naganowska B, Wolko B (2016) Expansion of the phosphatidylethanolamine binding protein family in legumes: a case study of Lupinus angustifolius L. FLOWERING LOCUS T homologs, LanFTc1 and LanFTc2. BMC Genomics 17:820. https://doi.org/10.1186/ s12864-016-3150-z

Książkiewicz M et al (2013) Comparative genomics of Lupinus angustifolius gene-rich regions: BAC library exploration, genetic mapping and cytogenetics. BMC Genomics 14:79. https://doi.org/ 10.1186/1471-2164-14-79

Książkiewicz M et al (2015) Remnants of the legume ancestral genome preserved in gene-rich regions: insights from Lupinus angustifolius physical, genetic, and comparative mapping. Plant Mol Biol Report 33:84-101. https://doi.org/10.1007/s11105-014-0730-4

Kwak M, Velasco D, Gepts P (2008) Mapping homologous sequences for determinacy and photoperiod sensitivity in common bean (Phaseolus vulgaris). J Hered 99:283-291. https://doi.org/10.1093/ jhered/esn005

Lambers H, Clements JC, Nelson MN (2013) How a phosphorusacquisition strategy based on carboxylate exudation powers the success and agronomic potential of lupines (Lupinus, Fabaceae). Am J Bot 100:263-288. https://doi.org/10.3732/ajb.1200474

Lee C, Yu D, Choi H-K, Kim RW (2017) Reconstruction of a composite comparative map composed of ten legume genomes. Genes \& genomics 39:111-119. https://doi.org/10.1007/s13258-016-0481-8

Leśniewska K, Książkiewicz M, Nelson MN, Mahé F, Aïnouche A, Wolko B, Naganowska B (2011) Assignment of 3 genetic linkage groups to 3 chromosomes of narrow-leafed lupin. J Hered 102:228236. https://doi.org/10.1093/jhered/esq107

Li J, Dai X, Liu T, Zhao PX (2012a) LegumeIP: an integrative database for comparative genomics and transcriptomics of model legumes. Nucleic Acids Res 40:D1221-D1229. https://doi.org/10.1093/nar/ gkr939

Li J, Dai X, Zhuang Z, Zhao PX (2016) LegumeIP 2.0-a platform for the study of gene function and genome evolution in legumes. Nucleic Acids Res 44:D1189-D1194. https://doi.org/10.1093/nar/gkv1237

Li L, Liu J, Xue X, Li C, Yang Z, Li T (2018) CAPS/dCAPS designer: a web-based high-throughput dCAPS marker design tool. Sci China Life Sci 61:992-995. https://doi.org/10.1007/s11427-017-9286-y

Li X, Buirchell B, Yan G, Yang H (2012b) A molecular marker linked to the mollis gene conferring soft-seediness for marker-assisted selection applicable to a wide range of crosses in lupin (Lupinus angustifolius L.) breeding. Mol Breed 29:361-370. https://doi.org/ 10.1007/s11032-011-9552-3

Li X, Renshaw D, Yang H, Yan G (2010) Development of a co-dominant DNA marker tightly linked to gene tardus conferring reduced pod shattering in narrow-leafed lupin (Lupinus angustifolius L). Euphytica 176:49-58. https://doi.org/10.1007/s10681-010-0212-1

Li X, Yang H, Buirchell B, Yan G (2011) Development of a DNA marker tightly linked to low-alkaloid gene iucundus in narrow-leafed lupin (Lupinus angustifolius L.) for marker-assisted selection. Crop Pasture Sci 62:218-224. https://doi.org/10.1071/CP10352

Li X, Yang H, Yan G (2012c) Development of a co-dominant DNA marker linked to the gene lentus conferring reduced pod shattering for marker-assisted selection in narrow-leafed lupin (Lupinus angustifolius) breeding. Plant Breed 131:540-544. https://doi.org/ 10.1111/j.1439-0523.2012.01978.x

Lin R et al (2009) Development of a sequence-specific PCR marker linked to the gene "pauper" conferring low-alkaloids in white lupin (Lupinus albus L.) for marker assisted selection. Mol Breed 23:153161. https://doi.org/10.1007/s11032-008-9222-2

Liu L, Adrian J, Pankin A, Hu J, Dong X, von Korff M, Turck F (2014) Induced and natural variation of promoter length modulates the photoperiodic response of FLOWERING LOCUS T. Nat Commun 5: 4558. https://doi.org/10.1038/ncomms5558

Manly KF, Robert H, Cudmore J, Meer JM (2001) Map Manager QTX, cross-platform software for genetic mapping. Mamm Genome 12: 930-932. https://doi.org/10.1007/s00335-001-1016-3 
McConnell M, Mamidi S, Lee R, Chikara S, Rossi M, Papa R, McClean P (2010) Syntenic relationships among legumes revealed using a gene-based genetic linkage map of common bean (Phaseolus vulgaris L). Theor Appl Genet 121:1103-1116. https://doi.org/10. 1007/s00122-010-1375-9

Mohamed AA, Rayas-Duarte P (1995) Composition of Lupinus albus. Cereal Chem 72:643-647

Mudge J, Cannon SB, Kalo P, Oldroyd GE, Roe BA, Town CD, Young ND (2005) Highly syntenic regions in the genomes of soybean, Medicago truncatula, and Arabidopsis thaliana. BMC Plant Biol 5:15. https://doi.org/10.1186/1471-2229-5-15

Neff MM, Neff JD, Chory J, Pepper AE (1998) dCAPS, a simple technique for the genetic analysis of single nucleotide polymorphisms: experimental applications in Arabidopsis thaliana genetics. Plant $\mathrm{J}$ 14:387-392. https://doi.org/10.1046/j.1365-313X.1998.00124.x

Neff MM, Turk E, Kalishman M (2002) Web-based primer design for single nucleotide polymorphism analysis. Trends Genet 18:613615. https://doi.org/10.1016/S0168-9525(02)02820-2

Nelson MN et al (2017) The loss of vernalization requirement in narrowleafed lupin is associated with a deletion in the promoter and derepressed expression of a Flowering Locus T (FT) homologue. New Phytol 213:220-232. https://doi.org/10.1111/nph.14094

Nelson MN et al (2010) Aligning a new reference genetic map of Lupinus angustifolius with the genome sequence of the model legume, Lotus japonicus. DNA Res 17:73-83. https://doi.org/10.1093/dnares/ dsq001

Nelson MN et al (2006) The first gene-based map of Lupinus angustifolius L.-location of domestication genes and conserved synteny with Medicago truncatula. Theor Appl Genet 113:225238. https://doi.org/10.1007/s00122-006-0288-0

O'Rourke JA et al (2013) An RNA-Seq transcriptome analysis of orthophosphate-deficient white lupin reveals novel insights into phosphorus acclimation in plants. Plant Physiol 161:705-724. https://doi.org/10.1104/pp.112.209254

Osorio CE, Udall JA, Salvo-Garrido H, Maureira-Butler IJ (2018) Development and characterization of InDel markers for Lupinus luteus L. (Fabaceae) and cross-species amplification in other Lupin species. Electron J Biotechnol 31:44-47. https://doi.org/10.1016/j. ejbt.2017.11.002

Papineau J, Huyghe C (2004) Le lupin doux protéagineux. France agricole, Paris

Parra-González LB et al (2012) Yellow lupin (Lupinus luteus L.) transcriptome sequencing: molecular marker development and comparative studies. BMC Genomics 13:425. https://doi.org/10.1186/14712164-13-425

Phan HTT, Ellwood SR, Adhikari K, Nelson MN, Oliver RP (2007) The first genetic and comparative map of white lupin (Lupinus albus L.): identification of QTLs for anthracnose resistance and flowering time, and a locus for alkaloid content. DNA Res 14:59-70. https:// doi.org/10.1093/dnares/dsm009

Porsche W (1964) Untersuchungen über die Vererbung der Alkaloidarmut und die Variabilität des Restalkaloidgehaltes bei Lupinus albus L. Der Züchter 34:251-256. https://doi.org/10.1007/ bf00705826

Przysiecka Ł, Książkiewicz M, Wolko B, Naganowska B (2015) Structure, expression profile and phylogenetic inference of chalcone isomerase-like genes from the narrow-leafed lupin (Lupinus angustifolius L.) genome. Front Plant Sci 6:268. https://doi.org/10. 3389/fpls.2015.00268

Rogers DJ, Tanimoto TT (1960) A Computer program for classifying plants. Science 132:1115-1118. https://doi.org/10.1126/science. 132.3434 .1115

Rychel S, Książkiewicz M, Tomaszewska M, Bielski W, Wolko B (2019) FLOWERING LOCUS T, GIGANTEA, SEPALLATA and FRIGIDA homologs are candidate genes involved in white lupin (Lupinus albus L.) early flowering. Mol Breed 39:43. https://doi.org/10. 1007/s11032-019-0952-0

Šatović Z (1993) Biokemijske i genetske osobine alkaloida bijele lupine (Lupinus albus.). Sjemenarstvo 10:139-154

Shavrukov Y (2016) Comparison of SNP and CAPS markers application in genetic research in wheat and barley. BMC Plant Biol 16:11. https://doi.org/10.1186/s12870-015-0689-9

Sokal RR, Michener CD (1958) A statistical method for evaluating systematic relationships. University of Kansas Scientific Bulletin 28: 1409-1438

Stam P (1993) Construction of integrated genetic linkage maps by means of a new computer package: Join Map. Plant J 3:739-744. https:// doi.org/10.1111/j.1365-313X.1993.00739.x

Stracke S, Sato S, Sandal N, Koyama M, Kaneko T, Tabata S, Parniske M (2004) Exploitation of colinear relationships between the genomes of Lotus japonicus, Pisum sativum and Arabidopsis thaliana, for positional cloning of a legume symbiosis gene. Theor Appl Genet 108:442-449. https://doi.org/10.1007/s00122-003-1438-2

Święcicki W Developments in L. albus breeding. In: 4th International Lupin Conference, Geraldton, Western Australia, 1986. International Lupin association, Canterbury, New Zealand and Department of Agriculture, Western Australia, pp 14-19

Święcicki W, Jach K (1980) Variation and evolution of alkaloid complex in yellow lupine (Lupinus luteus L.) during domestication Acta Agrobotanica 33:177-195

Święcicki W, Święcicki WK (1995) Domestication and breeding improvement of narrow-leafed lupin (L. angustifolius L.). J Appl Genet 36:155-167

Taylor CM et al (2019) INDEL variation in the regulatory region of the major flowering time gene $L a n F T c 1$ is associated with vernalization response and flowering time in narrow-leafed lupin (Lupinus angustifolius L.). Plant Cell Environ 42:174-187. https://doi.org/ 10.1111 pce. 13320

Thiel T, Kota R, Grosse I, Stein N, Graner A (2004) SNP2CAPS: a SNP and INDEL analysis tool for CAPS marker development. Nucleic Acids Res 32:e5-e5. https://doi.org/10.1093/nar/gnh006

Troll HJ (1958) Erbgänge des Alkaloidgehaltes und Beobachtungen über Heterosiswirkung bei Lupinus albus. Zeitschrift für Pflanzenzüchtung 39:35-46

Untergasser A, Nijveen H, Rao X, Bisseling T, Geurts R, Leunissen JAM (2007) Primer3Plus, an enhanced web interface to Primer3. Nucleic Acids Res 35:W71-W74. https://doi.org/10.1093/nar/gkm306

Vipin CA et al (2013) Construction of integrated linkage map of a recombinant inbred line population of white lupin (Lupinus albus L.). Breed Sci 63:292-300. https://doi.org/10.1270/jsbbs.63.292

von Sengbusch R (1942) Süßlupinen und Öllupinen. Die Entstehungsgeschichte einiger neuer Kulturpflanzen. Landwirtschaftliche Jahrbücher 91:719-880

Wang J et al (2017) Hierarchically aligning 10 legume genomes establishes a family-level genomics platform. Plant Physiol 174:284 300. https://doi.org/10.1104/pp.16.01981

Wyrwa K, Książkiewicz M, Szczepaniak A, Susek K, Podkowiński J, Naganowska B (2016) Integration of Lupinus angustifolius L. (narrow-leafed lupin) genome maps and comparative mapping within legumes. Chromosome Res 24:355-378. https://doi.org/10.1007/ s10577-016-9526-8

Yang H, Boersma JG, You M, Buirchell BJ, Sweetingham MW (2004) Development and implementation of a sequence-specific PCR marker linked to a gene conferring resistance to anthracnose disease in narrow-leafed lupin (Lupinus angustifolius L). Mol Breed 14: 145-151. https://doi.org/10.1023/B:MOLB.0000038003.49638.97

Yang H, Renshaw D, Thomas G, Buirchell B, Sweetingham M (2008a) A strategy to develop molecular markers applicable to a wide range of crosses for marker assisted selection in plant breeding: a case study on anthracnose disease resistance in lupin 
(Lupinus angustifolius L). Mol Breed 21:473-483. https://doi. org/10.1007/s11032-007-9146-2

Yang H, Shankar M, Buirchell J, Sweetingham W, Caminero C, Smith C (2002) Development of molecular markers using MFLP linked to a gene conferring resistance to Diaporthe toxica in narrow-leafed lupin (Lupinus angustifolius L). Theor Appl Genet 105:265-270. https://doi.org/10.1007/s00122-002-0925-1

Yang H et al (2013) Draft genome sequence, and a sequence-defined genetic linkage map of the legume crop species Lupinus angustifolius L. PLoS One 8:e64799. https://doi.org/10.1371/ journal.pone.0064799

Yang S et al (2008b) Alfalfa benefits from Medicago truncatula: the RCT1 gene from M. truncatula confers broad-spectrum resistance to anthracnose in alfalfa. Proc Natl Acad Sci U S A 105:12164 12169. https://doi.org/10.1073/pnas.0802518105
Yang T et al (2017) Transcript profiling of a bitter variety of narrow-leafed lupin to discover alkaloid biosynthetic genes. J Exp Bot 68:55275537. https://doi.org/10.1093/jxb/erx362

You M, Boersma JG, Buirchell BJ, Sweetingham MW, Siddique KHM, Yang H (2005) A PCR-based molecular marker applicable for marker-assisted selection for anthracnose disease resistance in lupin breeding. Cell Mol Biol Lett 10:123-134

Zhou G et al (2018) Construction of an ultra-high density consensus genetic map, and enhancement of the physical map from genome sequencing in Lupinus angustifolius. Theor Appl Genet 131:209223. https://doi.org/10.1007/s00122-017-2997-y

Publisher's note Springer Nature remains neutral with regard to jurisdictional claims in published maps and institutional affiliations. 